\title{
APPLICATION OF THE DESIGN THINKING METHOD IN CUSTOMER EXPERIENCE MANAGEMENT
}

\section{ZASTOSOWANIE METODY DESIGN THINKING W ZARZĄDANIU}

DOŚWIADCZENIAMI KLIENTÓW

\author{
Michał Prorok \\ SGH Warsaw School of Economics \\ mp60609@doktorant.sgh.waw.pl ORCID 0000-0003-0614-8527 \\ Izabela Kosicka \\ Euler Hermes Poland, Towarzystwo Ubezpieczeń S.A \\ izabela.kosicka@eulerhermes.com 0 ORCID 0000-0002-7562-2387 \\ DOl: $10.2478 /$ minib-2021-0020
}

\section{ABSTRACT}

The aim of this paper is to conceptualize Design Thinking and customer experience management (CEM), to situate the use of the Design Thinking method in customer experience management processes and to present its practical application based on a case study from the financial services industry - the trade credit insurer, Euler Hermes Poland, Towarzystwo Ubezpieczeń S.A. This article is an attempt to identify actionable Design Thinking process elements and tools and their intersections with the components of the Customer Experience Management processes.

Key words: design thinking, customer experience management, customer experience, customer journey map, persona 


\section{ABSTRAKT}

Celem artykułu jest konceptualizacja Design Thinking oraz wskazanie na zastosowanie tej metody w zarządzaniu doświadCzeniami klientów (ang. customer experience management - CEM), umiejscowienie wykorzystywania metody Design Thinking w procesach zarządzania doświadczeniami klientów oraz przedstawienie jej praktycznego zastosowania na przykładzie studium przypadku przedsiębiorstwa z branży finansowej - ubezpieczyciela należności handlowych, Euler Hermes Polska, Towarzystwo Ubezpieczeń S.A. Niniejszy artykuł jest próbą wskazania możliwych do zastosowania elementów procesu Design Thinking i narzędzi oraz ich punktów styku z częściami składowymi procesu zarządzania doświadczeniami klientów.

\section{Słowa kluczowe: design thinking, zarządzanie doświadczeniami klientów, doświadczenia klientów, mapa} podróży klienta, persona

JEL: M10, M30

\section{Introduction}

As early as 1999, Schmitt (1999) noted that we are in the midst of a revolution that will replace traditional marketing based on features and benefits with experiential marketing. In 1998, Pine and Gilmore (1998) had introduced the concept of the experience economy, which is meant to replace the service-based economy. Experience is a major component of experiential marketing and, according to LaSalle and Britton (2003) and Schmitt (1999), is one of the key developments in marketing in general. Although experience is now considered one of the key concepts in marketing, there are different views and interpretations regarding the definition of the specific terms. 
Although there is no clear definition in the literature, authors agree on the fact that customer experience is a multidimensional construct containing cognitive, affective, sensory, and environmental components. For the purpose of this study, the definition proposed by Verhoef et al. (2009, p. 32) is adopted because it is the most complete and comprehensive:

Customer experience construct is holistic in nature and involves the customer's cognitive, affective, emotional, social and physical responses to the retailer. This experience is created not only by those elements which the retailer can control (e.g., service interface, retail atmosphere, assortment, price), but also by elements that are outside of the retailer's control (e.g., influence of others, purpose of shopping). Additionally... the customer experience encompasses the total experience, including the search, purchase, consumption, and after-sale phases of the experience, and may involve multiple retail channels [...]

The authors drew attention to stimuli - that is, everything that the customer perceives and feels as present or past in the context of interactions with the company.

\section{Customer experience management}

Customer experience management (CEM) is a customer-centric management concept. Moreover, it is a process-oriented rather than an outcome-oriented concept and is characterized by strong linkages with various streams of management research (Hwang \& Seo, 2016). Some authors have indicated the need to extend market orientation by emphasizing a company's orientation towards the total customer experience, from pre-purchase to post-purchase (Blocker et al., 2011; Day, 2011).

Customer experience management is defined in the literature as "the process of strategically managing a customer's entire experience with a product or a company" (Schmitt, 2010, p. 17). The purpose of customer experience management is to gather customer feedback, identify business processes that need updating, and minimize negative customer experiences. Consistent positive customer experiences lead to improvements in business performance (Fatma, 2014). 
Carbone (2004) proposed the following framework for customer experience management:

1. Learn: experience evaluation, experience audit.

2. Create: designing experiences; creating an "experience theme" (the dominant idea or theme of the experience).

3. Execute: experience implementation, operational management.

The research company Forrester Research (2016) proposed an expanded framework presented by Carbone, creating six pillars of customer experience management along with their objectives, as presented in Table 1.

\section{Table 1. The constituent domains of Customer Experience Management}

\begin{tabular}{l|l}
\hline \multicolumn{1}{c|}{ Domain } & \multicolumn{1}{c}{ Goal } \\
\hline Customer understanding & $\begin{array}{l}\text { Providing management and employees with complete and accurate information about } \\
\text { customer needs and their evaluation of specific interactions and products }\end{array}$ \\
\hline Prioritization & $\begin{array}{l}\text { Concentrating the organization's resources on creating and delivering key customer } \\
\text { experiences that most importantly contribute to the company's goals }\end{array}$ \\
\hline Design & $\begin{array}{l}\text { Turning the company's experience vision into detailed plans and actions describing what } \\
\text { employees need to do to deliver the right customer experience every time }\end{array}$ \\
\hline Delivery & $\begin{array}{l}\text { Managing day-to-day operations to ensure that the customer experience matches the } \\
\text { designers' initial intent and meets the targeted objectives }\end{array}$ \\
\hline Measurement & $\begin{array}{l}\text { Defining the acceptable level of satisfaction of perceived customer experience, based on } \\
\text { the extent to which the experience has the characteristics intended by the company } \\
\text { (e.g., scope of information provided, speed of response to a request) and the impact the } \\
\text { experience has on transactional aspects }\end{array}$ \\
\hline Culture & $\begin{array}{l}\text { Embedding in the employees' attitudes the sorts of behaviors and attitudes that are } \\
\text { focused on delivering the best possible value to customers }\end{array}$ \\
\hline
\end{tabular}

Source: Forrester Research (2016). 


\section{Design Thinking}

Design Thinking is an approach that helps to answer questions regarding customers and their needs and expectations, which should be taken into consideration when designing or redesigning both products and services. According to Plattner (2009), the roots of the method can be found at the beginning of the 1960s, when cooperation between designers, engineers, and other business representatives - people from different backgrounds - became complex. Those people needed a common method enabling them to conduct creative processes in a collaborative way. The author underlined that partial solutions were then developed for the partial questions, which were combined to form an overall solution at the beginning of the 21 st century. During the 70 s and $80 \mathrm{~s}$, concepts related to design thinking appeared in the literature as "visual thinking," "mind mapping," and "human-centered design" (Curedale, 2013). Rowe (1987) can be recognized as the first author to use design thinking in the literature, who emphasized the idea of problem solving and the "complex texture of decision making," describing the design process as not restricted by an idealized step-by-step process, and stressing the ways in which designers approach creative problem solving. Through the 90s and into the 21st century, the term design thinking has evolved with numerous meanings. In 2008, Tim Brown presented the Design Thinking process used by IDEO. According to Brown (2008, p. 86), it is "a discipline that uses the designer's sensibility and methods to match people's needs with what is technologically feasible and what a viable business strategy can convert into customer value and market opportunity." This definition qualifies design thinking as both process ("methods") and as being human-centered ("sensibility") and clearly links design to business. The author describes a three-phase procedure model (inspiration, ideation, implementation) and how Design Thinking can be used within companies, but specific techniques were not included. Lockwood (2009, p. 5) states that DT is "a human-centered innovation process that emphasizes observation, collaboration, fast learning, visualization of ideas, rapid concept prototyping, and concurrent business analysis," thus emphasizing the application of a professional designer's work process based on observation, 
visualization, and prototyping. In contrast, Martin (2009, p. 28) emphasizes the thinking element, defining DT as "the productive mix of analytical thinking and intuitive thinking." In 2009, Plattner, Meinel and Weinberg (2009) presented the basic principles of the DT process used by the HassoPlattner-Institute in Potsdam, defining this approach as a systematic, user-oriented way to solve real-life problems, with the focus on addressing the user's needs and requirements. The authors underlined the importance of creating multidisciplinary teams and using techniques such as brainstorming and visualizing aimed at boosting creativity. It places special emphasis on customer understanding and observation which can be achieved by qualitative research and some techniques such as persona and storytelling. Plattner's findings were further extended by the Stanford Design School (d.school at Stanford University, 2018), which presented five phases process (empathy, define, ideate, prototype, test). This approach prefers doing over thinking, meaning that activity is more important than holding meetings and experiments are the best way to gain experience. Furthermore, various techniques (e.g.: What? How? Why?, Journey Maps, How Might We?, Wizzard of $\mathrm{Ozz}$ ) were outlined and described to be used during each phase of the DT process. Curedale (2013, p. 13) describes DT as a:

people centered way of solving difficult problems. It follows a collaborative team based cross-disciplinary process. It uses a toolkit of methods and can be applied by anyone from the most seasoned corporate designers and executives to schoolchildren. Design Thinking is an approach that seeks practical and innovative solutions to problems. It can be used to develop products, services, experiences and strategy [...]. Design Thinking combines empathy for people and their context with tools to discover insights. It drives business value.

Considering the most frequently cited stages of the DT process, some degree of similarity can be seen, even though different terms and sequences of activities are used, as shown in Table 2.

The DT process usually begins with an initial exploration aiming to understand the problem to be solved. This is the moment for a comprehensive approach to the topic, searching for information about the user through direct interaction, preferably in their environment, home or work. Research conducted during this stage - interviews, observations helps to look at the research problem from the customer's perspective and 
to get to know their situation. At this stage any information may prove useful. Then, all information about who the user is, what their biggest challenges and everyday problems are, what they need in the context of the solution designed, must be analyzed and narrowed down to one sentence, representing a design challenge.

\section{Table 2. Main stages of Design Thinking process}

\begin{tabular}{l|l}
\hline \multicolumn{1}{c|}{ Authors } & Main stages of Design Thinking process \\
\hline IDEO & 1. Inspiration \\
& 2. Ideation \\
& 3. Implementation \\
\hline Hasso-Plattner-Institute & 1. Understand \\
& 2. Observe \\
& 3. Point of View \\
& 4. Ideate \\
& 5. Prototype \\
& 6. Test \\
\hline Stanford Design School (d.school) & 1. Empathize \\
& 2. Define \\
& 3. Ideate \\
& 4. Prototype \\
& 5. Test \\
\hline
\end{tabular}

Source: Schallmo, Williams, and Lang (2018).

The next stage is ideation, which aims to generate a possible alternative. During this stage, many varieties of brainstorming and creative techniques are used to generate ideas that respond to a predefined design challenge. The result of this stage is the selection of several ideas for prototyping.

The stages of the DT process outlined in the literature end with the implementation and testing phase. Selected ideas are turned into prototypes, i.e., objects in the form of mock-ups, diagrams or storyboards, which show the most important functionalities and the way they could be used by customers. The purpose of all this is to be able to show the user a sample of the experience, i.e., how the solution will work in a specific situation and how it will solve their problems. The prototypes are then tested 
in order to identify those features and functionalities that will be further developed and eliminate those that have not gained the approval of customers.

According to Gartner and Ludwig (2015), regardless of the definition and phases chosen, Design Thinking is a process that can be described by following attributes:

- observation and understanding,

- user/customer orientation,

- interaction and experimentation,

- visualization,

- prototyping,

- structured collaboration.

Wojciechowska (2020) pointed out one additional, significant attribute, which is non-linearity. Working with the DT method is an iterative process, which might sometimes mean the need to go back to earlier stages, or even start the whole process over again. This may be due to team members noticing an error in their reasoning process or gaining new, surprising information.

Conducting the DT process using the attributes listed above requires knowledge and application of the various methods and tools (Table 3).

\section{Table 3. Design Thinking tools and methods}

\begin{tabular}{l|l|l}
\hline \multicolumn{2}{c|}{ Type } & \multicolumn{1}{c}{ Description } \\
\hline Tool & Persona & $\begin{array}{l}\text { Personas are symbolic representations of "typical" users-archetypes that } \\
\text { represent user patterns. Personas focus on individuals with whom the designer } \\
\text { might identify }\end{array}$ \\
\hline Method & $\begin{array}{l}\text { Customer journey map } \\
\text { A linear, time-based representation of the major stages a customer goes } \\
\text { through when interacting with a company or service } \\
\text { A visual representation of observational findings that enables conclusions to be } \\
\text { drawn from ethnographic data and create a common point of view among team } \\
\text { members }\end{array}$ \\
\hline $\begin{array}{l}\text { Erainstorming } \\
\text { Visualization }\end{array}$ & $\begin{array}{l}\text { Research methods such as observations, interviews, and user diaries } \\
\text { A collaborative process that encourages the exploration of new solutions that } \\
\text { may not be possible through individual ideas } \\
\text { Diagrams, cartoons, and stories that visualize a process, service, product or } \\
\text { interaction } \\
\text { Preparing demo versions of target solutions } \\
\text { The process of testing and analyzing the way the prototypes are used and } \\
\text { evaluated by target users/customers }\end{array}$ \\
\hline
\end{tabular}

Source: Adapted from: Micheli, Wilner, Bhatti, Mura, and Beverland (2019). 
It is worth mentioning that there is no single dominant way of doing things. Coming up with solutions using the Design Thinking method very often involves a unique composition of methods and tools, tailored to the business context and industry specifics.

\section{The role of Design Thinking in Customer Experience Management}

The role of Design Thinking in customer experience management processes may be considered on two levels (Micheli et al., 2019):

1. DT as a holistic process.

2. DT as a combination of methods and tools.

The relationship between DT as a holistic process and customer experience management is obvious to note. The DT process can be a way to approach experience design. It is desirable for several reasons:

- Design should be human-centered, and that is what DT is, it focuses on empathy with customers, rapid iterations, agility and simplicity.

- Involving company employees in the experience design process, which is one of the main attributes of DT, helps them empathize with customers, understand why certain things need to happen in a certain way, and report design issues early in the process so they can be addressed.

- Any interaction with a company should be aligned with the brand identity or support achieving the company's business goals. Management processes need to explicitly verify this, which is possible through the iterative prototyping and testing phases that are one of the main components of DT.

Considering Design Thinking methods as a set of tools and methods, beyond the area of experience design, also allows managers to better understand their customers and spread a customer-centric culture by encouraging employees from different departments to collaborate. 
The total role of the DT process in the customer experience management process can thus be captured by looking for the intersections between the two concepts. We have drawn up such a comparison in Table 4.

\section{Table 4. Intersections between Design Thinking and Customer Experience Management}

\begin{tabular}{l|c|c|c|c|c|c}
\hline \multirow{2}{*}{$\begin{array}{c}\text { Design } \\
\text { Thinking } \\
\text { method/tool }\end{array}$} & \multicolumn{5}{c}{ Customer Experience Management Domains } \\
\cline { 2 - 6 } & $\begin{array}{c}\text { Customer } \\
\text { understanding }\end{array}$ & Prioritization & Design & Delivery & Measurement & Culture \\
\hline Persona & $\mathrm{X}$ & & $\mathrm{X}$ & & & \\
Customer journey map & $\mathrm{X}$ & & $\mathrm{X}$ & & $\mathrm{X}$ & \\
Mind map & $\mathrm{X}$ & & $\mathrm{X}$ & & \\
Ethnography & $\mathrm{X}$ & & $\mathrm{X}$ & & \\
Brainstorming & & & $\mathrm{X}$ & & $\mathrm{X}$ \\
Visualization & & $\mathrm{X}$ & $\mathrm{X}$ & & $\mathrm{X}$ \\
Prototyping & $\mathrm{X}$ & $\mathrm{X}$ & $\mathrm{X}$ & & $\mathrm{X}$ \\
Field experiments & & $\mathrm{X}$ & $\mathrm{X}$ & & $\mathrm{X}$ & \\
\hline
\end{tabular}

\section{Persona}

Persona is used in the Design Thinking method mainly during the discovery stage and aims to see the problem from the customer's perspective (Michalska-Dominiak \& Grocholinski, 2019). It is an imaged representation of the customer, which includes certain demographic and social characteristics (age, education, place of residence, earnings), but also issues such as lifestyle, motivations and needs (especially in the context of purchasing or consuming the product offered by a given company), much more important in the context of experience management (Dziubecka \& Mlynarski, 2021). Developing a persona also allows you to complete a value proposition canvas (Osterwalder et al., 2014), which allows stakeholders to understand:

- Customers' jobs - important activities that customers want to complete or needs that they want to satisfy by purchasing a product or service.

- Pain points - barriers, obstacles, and inconveniences that customers experience when performing certain activities or interacting with 
a service/product.

- Gains - positive results obtained in the process of acquiring, consuming or prosuming a good.

According to Stickdorn, Hormess, Lawrence, and Schneider (2021), persona is an ideal tool for sharing research findings and insights with the design team and internal stakeholders. Thus, this tool fits perfectly not only in the area of design, but also in the area of understanding the customer in the context of managing the customer experience.

\section{Customer journey map}

The customer journey can be visualized using a customer journey map, which is a graphical representation of touchpoints (Halvorsrud, Kvale, \& Folstad, 2016). Touchpoints are "any verbal (e.g., advertising) or nonverbal (e.g., product use) events that a person perceives or consciously relates to a particular company or brand" (Homburg, Jozić, \& Kuehnl, 2017, p. 384). According to Richardson (2010), a customer journey map is a linear, timeline-based representation of the main stages a customer goes through when interacting with a company or service, while the customer experience is captured as a process, a flow covering all interaction from beginning to end, according to the customers' intentions, motivations and goals. A consistency can be found in the literature - that customer journey mapping is fundamental to improving the customer experience associated with a brand (Wódkowski \& Kosinski, 2021).

Wojciechowska (2020) notes that a customer journey map is one of the most widely used diagrams that illustrates a consolidated representation of the individual experiences perceived by the customer. It also enables the analysis of customer behavior and choices made by the customer at consecutive stages of the purchasing process, while adding also an emotional dimension related to the feelings of the individual in each of the interactions detailed. Therefore, this tool is an essential element in understanding the customer experience. By mapping the customer journey, the experience flow is broken down into several key stages. Starting with an analysis of user behavior, specific goals, intentions, touchpoints, tools, 
and problems are identified for each stage (Rudkowski et al., 2020). Finally, it allows a focus on the connections and dynamics between each stage. It is worth mentioning that a map is also an ideal starting point for measuring experiences. It allows touchpoints to be identified between the consumer and the company, which then should be included in the system for measuring the experiences occurring during the interaction.

\section{Ethnography}

The role of ethnography in the Design Thinking process is to enter the consumer's world and learn about their real needs. Maison (2015, p. 83) defines ethnographic research as "research conducted with the respondent in their natural environment: at home, at work, while shopping, walking or going to the pub in the evening." The author notes that the method plays a fundamental role in discovering who the product users really are, what their values and needs are, and what their lifestyle is. Chlodnicki (2018) notes the great importance of ethnographic methods such as: observation, shadowing and service safari. Dziubecka and Mlynarski (2021) emphasize that the findings gathered in the process of analyzing feedback derived from ethnographic research help to identify product users, reduce possible barriers to product access, learn about both customer motivations and needs, and identify errors in the product offered, which makes these methods ideal for understanding the customer experience.

\section{Mind map}

Wojciechowska (2020) observes that a mind map is used in the DT process as a tool for organizing ideas and research findings with the purpose of supporting the discovery and idea generation stages. Using this tool is about putting the main problem at the center and plotting the findings and insights from the ethnographic research around it, so that barriers, benefits, and needs emerging from the customer experience can be categorized. 


\section{Brainstorming/Visualization}

Brainstorming and techniques for visualizing problems or solutions are relevant both to project team members in the Design Thinking method and to collaborating with other stakeholders who have an interest in solving selected problems.

Brainstorming is about coming up with as many ideas as possible to solve a given problem. Several variations on this method can be distinguished, such as individual brainstorming, group brainstorming, mixed brainstorming, Philips 66 Buzz Sessions, brainstorming 653 (brainwriting) (Michalska-Dominiak \& Grocholinski, 2019). Regardless of the technique used to conduct a brainstorming session, it not only influences the experience design process but also shapes a customer-centric culture. Chlodnicki (2019) recommends inviting more employees to idea generation sessions. The author notes that involving internal stakeholders not only enables the exploration of different dimensions of a problem, but also increases employee involvement in creating solutions that directly affect them. This allows them to feel that they have an impact on their daily work.

Visualizing ideas, service diagrams, and processes can be used to enable continuous learning between internal stakeholders and allow sharing of concepts. Moreover, this method provides a more accessible way of explaining the features of a solution to the audience and makes it more susceptible to critical reflection and feedback generation (Glen et al., 2015). Micheli et al. (2019), on the other hand, emphasize that visualizations of ideas and solutions help to capture both current and desired states of experience, while seeding customer-centrism among internal stakeholders.

\section{Prototyping and field experiments}

In the DT method, prototyping consists of visualizing solutions in a way that allows for evaluating their quality, functionality, and adequacy at solving the problem defined for the project team. Prototyping serves several basic purposes. First, it allows a research activity that is used to create 
future solutions based on an initial concept and should be viewed as "thinking with your hands" to gain more information about the capabilities and challenges of the proposed solution. Second, prototyping helps to understand how customers will experience the good or service in the future. At this stage, it is important to use qualitative research methods that can provide some insights, facts and indicators (Stickdorn et al., 2021). These indicators can then form the basis for continuous measurement of customer experience. An iterative approach based on a loop of 3 steps is extremely important at this stage, as shown in Figure 1.

\section{Figure 1. The prototyping loop}

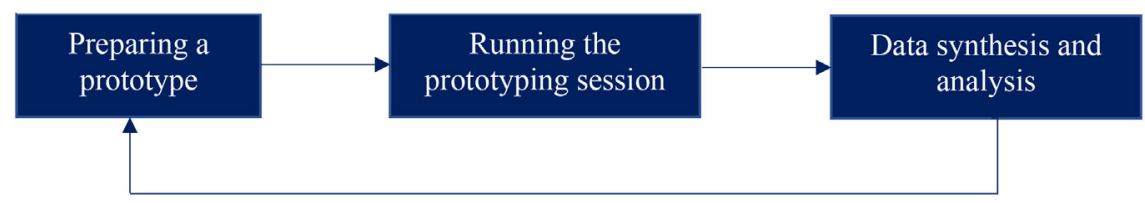

Source: Stickdorn, Hormess, Lawrence, and Schneider (2021)

Prototyping also contributes to reducing the options available and deciding what to focus on, which is prioritizing the experience. Moreover, prototyping also plays a key role in reducing misunderstandings and providing a platform for discussing the key functionality of the solution. The prototypes themselves can also act as information carriers or requisites when presenting the solution to a wider audience. Moreover, prototype presentations can be an excellent strategic tool for presenting ideas and engaging internal stakeholders, thus fostering a customer-centric culture (Stickdorn et al., 2021). 


\section{An applied example of using the Design Thinking method in customer experience management by an insurance company}

\section{Research methodology}

The following section of the paper uses the case study method, which is used in the early stages of identifying a research problem (Czakon, 2020). Czakon (2020, p. 190) emphasizes that a case should be considered as "a single research object, recognized for a specific purpose, situated at a specific place and time, given its own circumstances, and studied using multiple data collection and analysis techniques..." The research object in this case is the process implemented by the company (Dyer and Nebeoka, 2000).

This case was selected based on purposive selection, using the pragmatic criteria of data availability. A company in the insurance industry was chosen because it is an environment with a significant degree of formalization of knowledge, which makes it possible to make use of the analysis of the data obtained.

The purpose of the study has a practical orientation, assuming an illustrative and training purpose. Niemczyk emphasized that such an objective serves to understand the circumstances and decision-making paths of specific decision makers under specific circumstances (Niemczyk 2002).

Two methods of data collection were used: an in-depth interview with the manager of the process carried out by the company and a content analysis of the materials that were developed in the course of carrying out the process. The collected data were organized using time-based extraction, which Czakon (2020, p. 204) describes as "organizing the description of the process flow due to key phases, including the relationships between phases..." As a result, a logical and time-based pattern can emerge, which is then analyzed by considering its internal structure (components, consequences, and features of developmental stages) (Czakon, 2020). 


\section{Information about the company analyzed}

The company, Euler Hermes Towarzystwo Ubezpieczeń S.A., is an international financial and insurance group that has been supporting entrepreneurs in running their business for over 100 years in general and since 1998 on the Polish market. It is a leader in the Polish market, offering the following products: credit insurance, debt collection and court debt collection, insurance guarantees (surety), assessment of the financial condition of business entities, helping their clients - entrepreneurs choose safe markets to conduct business, as well as reliable contractors. An important part of the Group's new strategy is focusing on customers and their needs - True Customer Centricity / Customer Excellence. The company's ambition is to maintain a global and strategic local market leadership position in customer satisfaction surveys carried out annually in all company units using the same methodology and research questionnaires by the IPSOS marketing research agency.

\section{Challenge}

By assessing all touchpoints experienced by customers of the company as part of the identified customer journey, the Euler Hermes insurer was the market leader on the local market in 2019 in 5 areas: contract start and renewal, customer service, payment and compensation process, and online service systems. On the other hand, one of the main factors influencing the customer experience - the area of risk-taking and credit limit management, achieved one of the lowest levels of satisfaction and decreased significantly compared to 2017 , and was also rated the worst in relation to competitors. A factor that had a large impact on the customer experience in the area of risk assessment and one of the worst rated was the clarity and simplicity in explaining restrictive credit decisions: reduction, rejection, withdrawal or partial reduction of insurance protection. This challenge concerned the segment of small and medium-sized enterprises.

Based on the analysis of the detailed results, it has been recommended to launch an interdisciplinary project aimed at improving the customer experience in the SME segment in the area of communication and explaining restrictive credit decisions. Design Thinking was the 
recommended methodology to find potential solutions to this problem. The organization decided on this choice as a method of avoiding the daily routine and corporate silos, to have a broader perspective and to adopt the client's perspective, which, according to the management, should lead to the creation of a solution corresponding to the real needs of clients.

\section{Persona}

As part of the stage of understanding customer needs, the project team conducted a thorough analysis of the company's process related to restrictive credit decisions of the company (refusal, reduction, partial granting, withdrawal of protection) and based on the results of the analysis of customer statements/verbatim and their own experiences, created a persona for customers, which is presented in table 5 .

\section{Table 5. Persona of a customer from the SME segment, who purchases credit insurance contract}

\section{"Trans Janusz" - a small family transport company from Pruszków}

Company characteristics:

- no financier,

- limited budget,

- no person responsible for contact with the insurer,

- no selection of partners,

- every contract is important,

- no control system.

The owner is a person managing the company:

- precise,

- specific,

- interested in gaining the profit,

- interested in good relations with his customers.
Company goals:

- development,

- customer acquisition,

- maintaining financial liquidity.

Challenges:

- problems with receivables/ liquidity,

- difficulties in verifying a foreign traders.

Service expectations:

- the ability to quickly verify a potential customer,

- own risk reduction,

- business partnership,

- professional service, simple and fast. 
The next step was to complete the value proposition canvas in order to create research questions to be checked with the real users of the products of the company.

\section{Figure 2. Diagram of the value proposition for the persona from the SME segment}

Value proposition

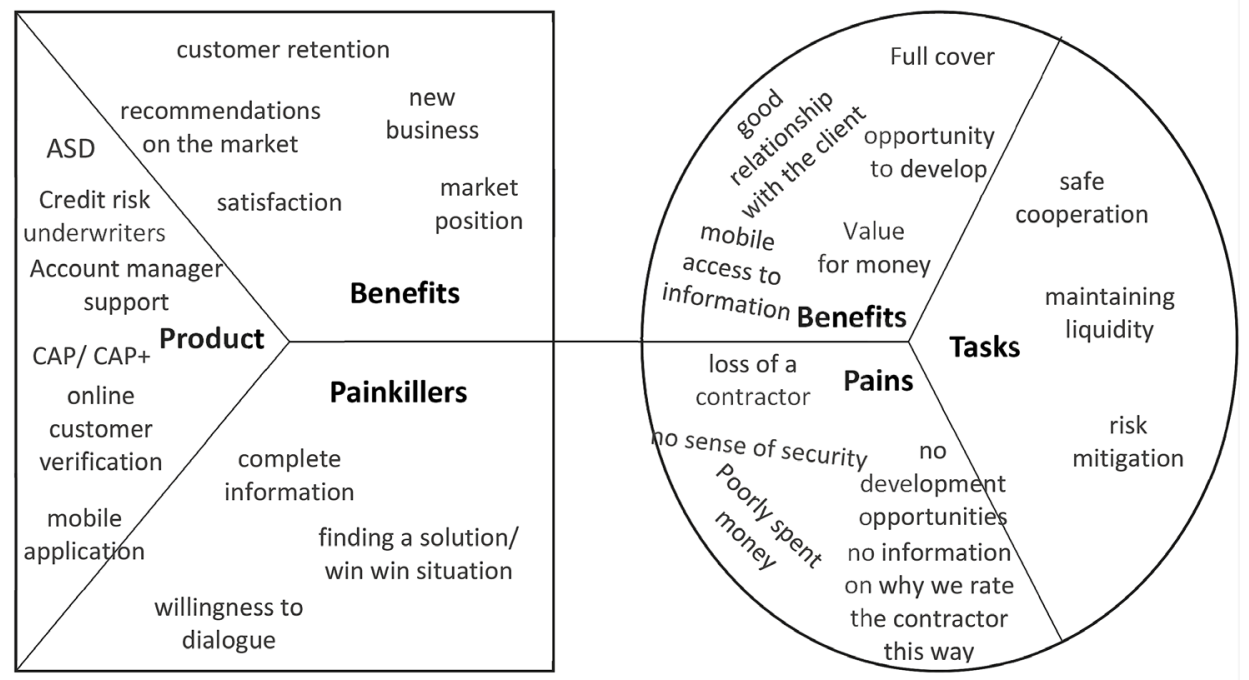

Source: internal company materials

\section{Ethnography}

Another workshop conducted by the project team was to design and prepare a qualitative study. The method of individual in-depth interviews was selected, which was conducted with 25 customers from the SME segment who experienced restrictive credit decisions. Importantly, the customer sites were chosen as the location for the interviews to better understand the environment in which they operate. Based on the assumptions made, an interview scenario was prepared to help answer the following research questions: 
- How do customers use trade credit insurance in their business?

- What is the biggest challenge in using trade credit insurance?

- What experiences do customers have with the assessment of credit limits?

- What work do customers have to do for the enterprise to continue to function despite a restrictive credit decision?

- What do customers think the ideal process for getting notified that a credit limit cannot be granted should look like?

The most important conclusions were selected from the in-depth interviews:

- Restrictive credit decisions involve a lot of emotion among SME clients - they affect their business and their future.

- Long-term clients developed their own actions in the event of receiving a restrictive credit decision.

- General confusion of clients in procedures, insurance rules, lack of communication, current messages are too complex and incomprehensible.

- Opinions in the form of decisions on granting a credit limit and its amount seem very credible to clients and they base their further actions on them. Customers trust the company's risk assessment.

- Customers believe that the restrictive limit decision does not contain enough details and explanations, they want to know what is really going on with the contractor, and do not find explanations in the letter due to the unintuitive, outdated form of the document.

- Customers praise the contact with the customer service office.

\section{Customer journey map}

A customer journey mapping workshop was conducted with the project team using the customer journey maps used so far by the company as a starting point and enriching them with customer feedback from interviews (Figure 3). 
Figure 3. Customer journey map (SME segment) — credit risk assessment process

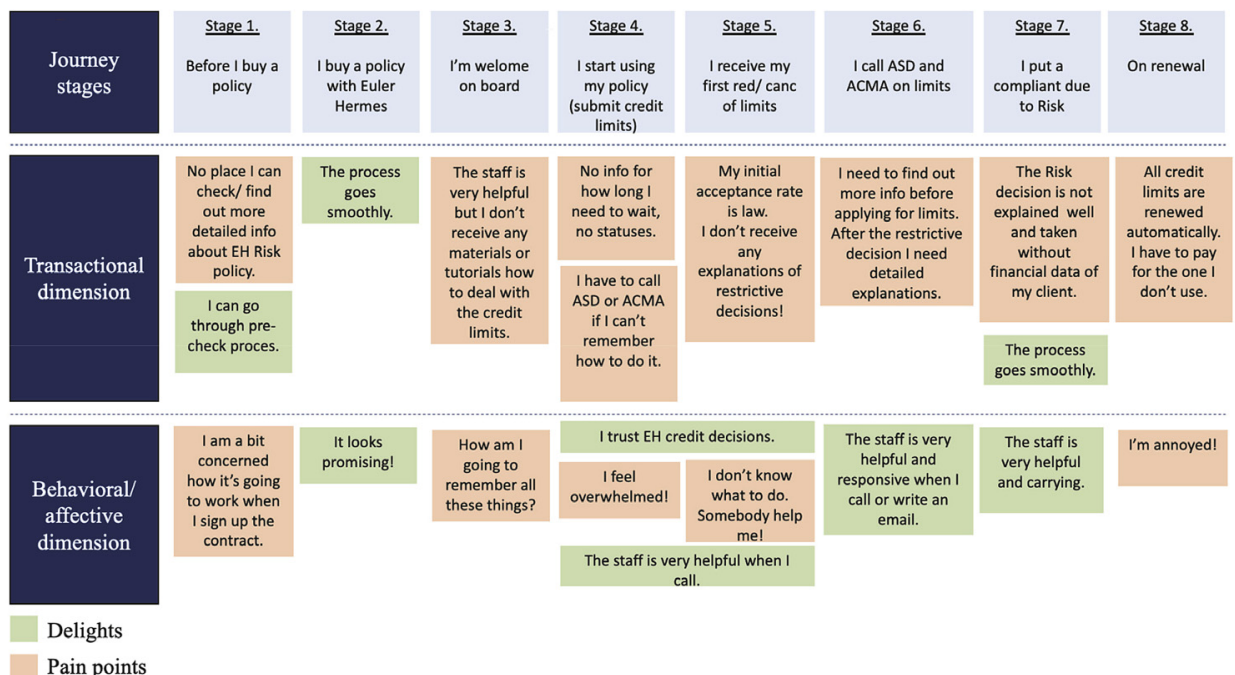

Source: internal company materials

It is worth noting that in the case of this process, the customer journey map also served the project team as a method of visualizing the research results.

\section{Brainstorming}

Based on the information collected and grouped from individual interviews with current customers and the customer journey map, another project team workshop was conducted, the purpose of which was to become acquainted with the results of the research and on their basis to define the client's problem, as well as to develop appropriate solutions. The following challenge was defined to be solved: "How to help TRANS JANUSZ, so that when he receives an unexpected restrictive limit decision (refusal, reduction or granting an incomplete credit limit), he feels calm, confident and safe and experiences good value from the money paid for insurance?" 
The phase of generating ideas and solutions was carried out using the specific brainstorming method which was Osborn's list in order to stimulate the team's creativity and go beyond the framework of daily procedures and automatically performed tasks. The solutions developed during the workshops can be divided into two main categories: improvement of internal processes and external solutions for customers.

Potential solutions in the area of internal processes:

- Development and implementation of customer service standards in the field of restrictive credit decisions, considering the needs of individual customer segments.

- Implementation of a new restrictive credit decision template, which will have a more user-friendly and transparent form.

Potential, external solutions for customers:

- Automatic sending of short, recorded comments on the topics described above to SME customers.

- Creating simple and modern supporting materials for customers in an electronic version available in the insurance contract handling system and automatically directed from the marketing automation system after each restrictive credit decision explaining in more detail, for example, the automatic codes used for credit decisions made, along with the system of their gradation ( yellow, orange, red alert - drawing attention to the probability of non-payment by the contractor) and indicating possible solutions for the insured entrepreneur.

\section{Prototyping/Field experiments}

For the prototyping and testing stage, the company chose three solutions: webinars for customers, a new layout for restrictive decisions on granting limits in the electronic customer panel, and the introduction of two types of negative messages (temporary and permanent negative decisions) regarding granting a credit limit from the marketing automation system. The prototype of each of the selected solutions was presented to a random group of customers, and its impact on consumer decisions was tested, which is presented in Table 6. 


\section{Table 6. Prototype testing}

\begin{tabular}{l|l|l}
\hline \multicolumn{1}{c|}{ Solution } & \multicolumn{1}{c}{ Testing process } & \multicolumn{1}{c}{ Results } \\
\hline $\begin{array}{l}\text { Webinars } \\
\text { for customers }\end{array}$ & $\begin{array}{l}\text { - Conducting 2 webinars for 269 clients } \\
\text { - Conducting a webinar satisfaction survey } \\
\text { - Analysis of contacts with the customer } \\
\text { service office caused by a negative decision } \\
\text { to grant limits }\end{array}$ & $\begin{array}{l}\text { - Reduction of the percentage of customers } \\
\text { contacting the customer service office by } 5 \% \\
\text { Average customer satisfaction: } \\
4.71 \text { (on a scale of 1-5) }\end{array}$ \\
\hline $\begin{array}{l}\text { Two types of negative } \\
\text { messages regarding } \\
\text { granting a credit limit } \\
\text { temporary or } \\
\text { permanent negative } \\
\text { decision) }\end{array}$ & $\begin{array}{l}\text { - Sending test messages for } 250 \text { clients } \\
\text { service office caused by a negative decision } \\
\text { to grant limits }\end{array}$ & $\begin{array}{l}\text { Reduction of the percentage of customers } \\
\text { contacting the customer service office by } 5 \%\end{array}$ \\
$\begin{array}{l}\text { New layout of the } \\
\text { restrictive decision } \\
\text { on granting limits } \\
\text { in the electronic } \\
\text { customer panel }\end{array}$ & - Creating a mock-up \\
\hline
\end{tabular}

Source: internal company materials

All the tested solutions turned out to have a positive impact on the customer experience, which reduced the percentage of people contacting the customer service office. The company decided to implement webinar solutions immediately and introduce two different decisions to refuse to grant credit limits. The solution for changing the layout of the negative decision was classified as requiring further analysis due to the complexity and high cost of IT implementation.

\section{Summary}

The Design Thinking method is useful in both designing new and modifying existing products (services and goods) and contributes to create unique customer experiences. Moreover, it is fundamental in the process of customer experience management, because it allows for a better customer 
understanding, prioritizing activities, measuring new experiences, and contributes to building a customer-centric culture. It also increases the involvement of employees, who have an opportunity to create a solution that meets the expectations of customers from scratch, and then to implement and monitor its effects. There are implications for the practical application of the method described in the case study. Considering the procedural issues, one of the most important conclusions is the creation of an interdisciplinary team, which in the company analyzed proposed potential solutions to the problem on two different levels: marketing communication and IT infrastructure. Moreover, such a team was also able to implement a prototype for solutions in a short time and test it, while examining their impact on customer interactions with the customer service office. Another issue is organizing the process, the backbone of which is tools allowing the problem to be viewed from the customer's point of view (persona) and a comprehensive analysis of the needs and natural behaviors of customers (customer journey map). The value proposition map, in turn, allowed the aforementioned needs to be translated into the target features and benefits of the service. It is worth mentioning that the research method applied has its limitations, as only the case of a single project implemented by a specific company in one industry was considered. Therefore, this topic has the potential to verify the stages of the Design Thinking process and the tools used. Another issue is examining the extent to which their application affects the achievement of the objectives of individual projects or the impact of the projects/processes implemented on the perception of products/services, or individual interactions with a given company in the long term. From this perspective, the application value of this article also lies in the identification of applicable methods and tools as well as their connections with the components of the customer experience management process.

\section{References}

1. Blocker, C. P., Flint, D. J., Myers, M. B., \& Slater, S. F. (2011). Proactive customer orientation and its role for creating customer value in global markets. Journal of the Academy of Marketing Science, 39(2), 216-233.

2. Brown, T. (2008). Design Thinking. Harvard Business Review, 86(6), 84. 
3. Carbone, L.P. (2004). Clued In: How to Keep Customers Coming Back Again and Again. New York: Prentice Hall.

4. Chłodnicki, M. (2018). Service design po polsku [Service Design the Polish Way]. Warsaw: Wydawnictwo Naukowe PWN.

5. Curedale, R. (2013). Design thinking pocket guide. Topanga, CA: Design Community College Inc.

6. Czakon, W. (2020). Podstawy metodologii badań w naukach o zarzadzaniu [Foundations of Research Methodology in Management Science], Warsaw: Wydawnictwo Nieoczywiste.

7. Day, G. S. (2011). Closing the marketing capabilities gap. Journal of marketing, 75(4), $183-195$.

8. d.school at Stanford University (2018). Design Thinking Bootcamp Bootleg, accessed 15 December 2021, <https://dschool.stanford.edu/resources/design-thinking-bootleg>

9. Dziubecka, J. \& Młynarski, G. (2021). Badania w procesach projektowania usług [Research in Service Design Processes], In: Lutostański, M. J., Łebkowska, A. \& Protasiuk M. (ed.), Badanie rynku: Jak zrozumieć konsumenta (24, 632-649), Warsaw: Wydawnictwo Naukowe PWN.

10. Dyer, J. H. \& Nobeoka, K. (2000). Creating and managing a high-performance knowledge-sharing network: the Toyota case. Strategic management journal, 21(3), 345-367.

11. Fatma, S. (2014). Antecedents and consequences of customer experience management A literature review and research agenda. International Journal of Business and Commerce, 3(6), 32-49.

12. Forrester Research (2016). The Customer Experience Management Maturity Model, Vision: The Customer Experience Maturity Playbook. Cambridge: Forrester Research.

13. Gartner, Ch. \& Ludwig, R. (2015). Design-Thinking im Projektmanagement. Zeitschrift fur Organization, April 2015, 255-261.

14. Glen, R., Suciu, C., Baughn, C. C., \& Anson, R. (2015). Teaching design thinking in business schools. The International Journal of Management Education, 13(2), 182-192.

15. Halvorsrud, R., Kvale, K., \& Folstad, A. (2016). Improving service quality through customer journey analysis. Journal of Service Theory and Practice. 3(6), 840-867.

16. Homburg, C., Jozić, D., \& Kuehnl, C. (2017). Customer experience management: toward implementing an evolving marketing concept. Journal of the Academy of Marketing Science, 45(3), 377-401.

17. Hwang, J. \& Seo, S. (2016). A critical review of research on customer experience management: Theoretical, methodological and cultural perspectives. International Journal of Contemporary Hospitality Management. 28(10), 2218-2246.

18. LaSalle, D. \& Britton, T.A. (2003). Priceless: Turning Ordinary Products into Extraordinary Experiences. Boston: Harvard Business School Press.

19. Lockwood T. (2009). Frameworks of design thinking. Design management Journal. 4(1), 33-47.

20. Maison, D. (2015). Jakościowe metody badań marketingowych — Jak zrozumieć konsumenta? [Quality Marketing Research Methods - How to Understand the Customer?]. Warsaw: Wydawnictwo Naukowe PWN. 
21. Martin R. (2009). The design of business: Why design thinking is the next competitive advantage. Boston: Harvard Business Press.

22. Michalska-Dominiak, B. \& Grocholiński, P. (2019). Poradnik Design Thinking [Guide to Design Thinking]. Gliwice: Helion.

23. Micheli, P., Wilner, S. J., Bhatti, S. H., Mura, M., \& Beverland, M. B. (2019). Doing design thinking: Conceptual review, synthesis, and research agenda. Journal of Product Innovation Management, 36(2), 124-148.

24. Niemczyk, J. (2002). Analogie w naukach o zarządzaniu [Analogies in Management Science]. Organizacja i Kierowanie, 3, 3-18.

25. Osterwalder, A., Pigneur, Y., Bernarda, G., \& Smith, A. (2014). Value proposition design: How to create products and services customers want. Vol. 2. New Jersey: John Wiley \& Sons.

26. Pine II, B. J. \& Gilmore, J. H. (1998). Welcome to the experience economy. Harvard Business Review Press. 76(4), 97-105.

27. Plattner, H., Meinel, C., \& Weinberg, U. (2009). Design thinking: Innovation lernen Ideenwelten öffnen. München: moderne industrie.

28. Richardson, A. (2010). Using customer journey maps to improve customer experience. Harvard Business Review, 15(1), 2-5.

29. Rowe, P. G. (1987). Design thinking. London, England: MIT Press.

30. Rudkowski, J., Heney, C., Yu, H., Sedlezky, S., \& Gunn, F. (2020). Here Today, Gone Tomorrow? Mapping and modeling the pop-up retail customer journey. Journal of Retailing and Consumer Services, 54, 1-25.

31. Schallmo, D., Williams, C. A., \& Lang, K. (2018). An integrated design thinking approach - literature review, basic principles and roadmap for design thinking. ISPIM Innovation Symposium. The International Society for Professional Innovation Management (ISPIM), 1-18.

32. Schmitt, B. H. (1999). Experiential Marketing. Journal of marketing management, 15(1-3), 53-67.

33. Schmitt, B. H. (2010). Customer Experience Management: A Revolutionary Approach to Connecting with Your Customers. New Jersey: John Wiley \& Sons.

34. Stickdorn, M., Hormess, M. E., Lawrence, \& A., Schneider, J. (2021). Jak projektować ustugi [How To Design Services]. Gliwice: Helion.

35. Verhoef, P. C., Lemon, K. N., Parasuraman, A., Roggeveen, A., Tsiros, M., \& Schlesinger, L. A. (2009). Customer experience creation: Determinants, dynamics and management strategies. Journal of Retailing, 85(1), 31-41.

36. Wojciechowska, K. (2020). Customer Experience Management - moc pozytywnych doświadczeń na ścieżce Twojego klienta [Customer Experience Management — The Power of Positive Experience on Your Customer's Journey]. Gliwice: Helion.

37. Wódkowski A. \& Kosiński G. (2021). Badania satysfakcji konsumentów [Studying Customer Satisfaction]. In: Lutostański, M. J., Łebkowska, A. \& Protasiuk M. (ed.), Badanie rynku: Jak zrozumieć konsumenta (24, 473-502) Warsaw: Wydawnictwo Naukowe PWN. 
Michał Prorok - PhD Student at the SGH Warsaw School of Economics and Customer Experience Manager at TEB Akademia. His research interests cover customer experience and customer experience management.

Izabela Kosicka - Customer Experience Manager, passionate in creating outstanding customer experiences in all touchpoints within the financial industry (B2B, B2C). Her professional mission is to enhance constant change and professionalization of both products and services for consumers. 